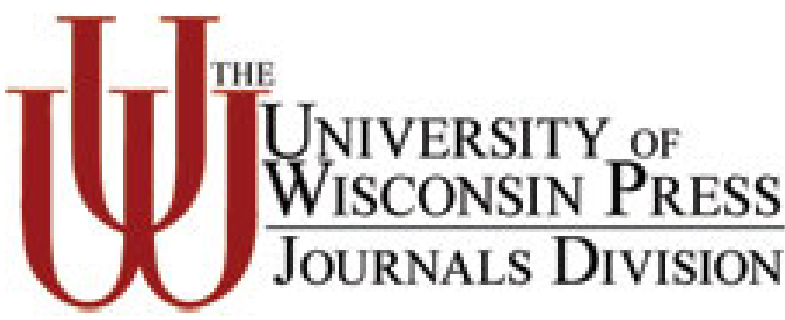

Drift and Pluralization in International Trade

Author(s): Francis A. Beer and Elliot Z. Wyner

Source: International Organization, Vol. 28, No. 1 (Winter, 1974), pp. 119-125

Published by: University of Wisconsin Press

Stable URL: http://www.jstor.org/stable/2706122

Accessed: $25 / 03 / 2014$ 13:39

Your use of the JSTOR archive indicates your acceptance of the Terms \& Conditions of Use, available at http://www.jstor.org/page/info/about/policies/terms.jsp

JSTOR is a not-for-profit service that helps scholars, researchers, and students discover, use, and build upon a wide range of content in a trusted digital archive. We use information technology and tools to increase productivity and facilitate new forms of scholarship. For more information about JSTOR, please contact support@jstor.org. 


\title{
DRIFT AND PLURALIZATION IN INTERNATIONAL TRADE
}

\author{
Francis A. Beer and Elliot Z. Wyner
}

In recent years, a considerable body of literature has dealt with relations between the so-called developed and developing nations. More recently, a number of analysts have attempted to gain leverage over the problem by utilizing a systemic perspective that links centers and peripheries. ${ }^{1}$

A basic hypothesis suggests a relationship of drift, in which the more and the less developed nations seem to be moving further apart. In particular, Jorge Domínguez in a recent article hypothesized that there is an "increasing economic fragmentation between the countries of the center and the peripheries." Domínguez verified the hypothesis by comparing trade over time, utilizing two types of statistics: an index of relative acceptance (RA), and two indices of economic importance (EIp and EIc). ${ }^{2}$

We believe that relations are somewhat more complex than a simple drift hypothesis suggests. Domínguez's research emphasized the relaxation in relations between nations formerly bound by bilateral colonial ties. Although Domínguez included twelve countries in his definition of the center, he only presented data supporting drift between the single most dominant center nation and a peripheral region, for example, between Morocco and France, Tunisia and France.

We suggest that individual cases of drift go together with a more general pattern of pluralization. Within this larger frame, specific

Francis A. Beer and Elliot Z. Wyner are associated with the Department of Government at the University of Texas at Austin. The authors thank the Institute for Latin American Studies at the University of Texas which provided assistance for the preparation of this article.

${ }^{1}$ See, for example, Johan Galtung, "A Structural Theory of Imperialism," Journal of Peace Research, No. 2 (1971), 81-117; Silvert Langholm, "On the Concepts of Center and Periphery," Journal of Peace Research, Nos. 3-4 (1971), 273-78; Steven J. Brams, "A Note on the Cosmopolitanism of World Regions," Journal of Peace Research, No. 1 (1968), 87-95.

${ }^{2}$ Jorge I. Domínguez, "Mice That Do Not Roar: Some Aspects of International Politics in the World's Peripheries," International Organization, XXV, 2 (Spring, 1971), 186. 
central nations may be drifting apart from peripheral states, but this is not necessarily true for central nations taken as a whole. Rather, there is an asymmetrical relationship-with substantial stability over time-in which the aggregate center remains more important to the periphery than vice versa. The declining salience of some central relations is counterbalanced by a growth in the importance of the others.

In our research, we defined the center in accordance with the definition of the "developed areas" used in the International Monetary Fund's publication, Direction of Trade. ${ }^{3}$

\section{DEVELOPED AREAS}

Industrial Countries
Austria
Belgium-Luxembourg
Canada
Denmark
France
Germany, Fed. Rep.
Italy
Japan
Netherlands
Norway
Sweden
Switzerland
United Kingdom
United States

Other Developed Areas

Finland

Greece

Iceland

Ireland

Portugal

Spain

Turkey

Yugoslavia

Australia

New Zealand

South Africa

Malta, post-1964

The peripheries on which we concentrated were the regions of North Africa (Morocco, Algeria, Tunisia, Libya) and Latin America during the period 1938-1970. We decided to use statistics associating percentages of trade, including EIp and EIc. ${ }^{4}$

\footnotetext{
${ }^{3}$ This measure differs from Domínguez's theoretical center in that it excludes the Sino-Soviet group: the Union of Soviet Socialist Republics, the People's Republic of China, and the socialist nations of Eastern Europe. However, it includes all the nations of Western Europe-Austria, Belgium, Denmark, Finland, France, Federal Republic of Germany, Greece, Iceland, Ireland, Italy, Luxembourg, Malta, Netherlands, Norway, Spain, Sweden, Switzerland, Turkey, Yugoslavia-as well as the United States, Canada, Japan, Australia, New Zealand, South Africa. Together these center nations represent over 80 percent of the world's trade.

${ }^{4} E I p$ refers to the economic importance of the center for the periphery. The periphery's exports to the center, as a percentage of the periphery's total exports, are added to the periphery's imports from the center, as a percentage of the periphery's total imports.

$E I c$ refers to the economic importance of the periphery for the center. The center's exports to the periphery, as a percentage of the center's total exports, are added to the center's imports from the periphery, as a percentage of the center's total imports.

These statistics were chosen because they had been used by Domínguez and would thus render our work directly comparable to his. Further, they were easily
} 
In North Africa, we see clearly the disengagement between the former colonial center and the peripheral region (tables 1 and 2). There was a clear postwar decline in French economic importance from 62.3 percent of North African imports and 72.2 percent of exports in 1938 to 34.7 percent and 26.7 percent, respectively, in 1970 .

There was an offsetting pattern of increasing relations between other nations of the center and North Africa. During this period, the aggregate center retained its position, even picking up a little ground, as other nations more than took up the slack from the French decline. In 1938 the United States, Great Britain, and Western Europe shared 91.5 percent of North African exports and supplied 75.4 percent of North African imports. In 1970 this same group shared 92.5 percent of all North African exports and 83.8 percent of the area's imports. TABLE 1. SOURCE OF NORTH AFRICAN IMPORTS AS A
PERCENTAGE OF TOTAL IMPORTS

\begin{tabular}{lrrrrrrrrr}
\hline \hline & 1938 & 1948 & 1958 & 1960 & 1962 & 1964 & 1966 & 1968 & 1970 \\
\hline United States & 2.8 & 10.84 & 6.66 & 5.11 & 11.42 & 11.15 & 11.84 & 13.33 & 11.41 \\
United & & & & & & & & & \\
$\quad$ Kingdom & 2.72 & 1.43 & 2.47 & 3.09 & 3.84 & 5.92 & 5.35 & 5.42 & 5.25 \\
Western & & & & & & & & & \\
$\quad$ Europe a & 69.90 & 70.26 & 80.63 & 80.76 & 71.99 & 66.94 & 64.89 & 63.13 & 67.10 \\
EEC & 67.89 & 68.28 & 76.97 & 77.02 & 68.62 & 62.76 & 59.61 & 56.75 & 58.80 \\
France & 62.33 & 65.66 & 70.86 & 68.46 & 56.43 & 48.69 & 41.27 & 33.25 & 34.68 \\
Germany & 1.28 & .34 & 2.14 & 3.13 & 3.69 & 4.98 & 5.67 & 7.35 & 8.42 \\
Italy & 1.36 & .70 & 2.40 & 3.62 & 5.53 & 6.16 & 9.39 & 11.45 & 10.74 \\
Sino Soviet & 4.4 & 1.2 & 1.48 & 3.18 & 4.43 & 7.89 & 8.13 & 8.06 & 5.94 \\
Japan & 2.64 & .20 & .20 & .30 & .66 & 1.08 & 1.08 & .72 & 1.35 \\
\hline
\end{tabular}

a Austria, Belgium, Denmark, Finland, France, Federal Republic of Germany, Greece, Iceland, Ireland, Italy, Malta, Luxembourg, Netherlands, Norway, Portugal, Spain, Sweden, Switzerland, Turkey, Yugoslavia.

b Incomplete data.

calculable and the results appeared generally consistent with those obtained through use of the relative acceptance (RA) index.

Nevertheless, it is important to bear in mind that such statistics have specific theoretical and methodological implications. Theoretically, they imply the independence anci reality of nationally aggregated data; they obscure patterns of subnational trade as well as the effects of bodies such as multinational corporations. Methodologically, they include a statistical control for total trade, which focuses on relative rather than absolute increases or decreases. For further discussion of the comparative strengths, weaknesses, and relations of other transaction statistics, see: Donald J. Puchala, "International Transactions and Regional Integration," in Leon N. Lindberg and Stuart A. Scheingold (eds.), Regional Integration: Theory and Research (Cambridge, Mass.: Harvard University Press, 1971) ; and James A. Caporaso, "Theory and Method of the Study of International Integration," International Organization, XXV, 2 (Spring, 1971) , 228-53. 
TABLE 2. DESTINATION OF NORTH AFRICAN EXPORTS AS A PERCENTAGE OF TOTAL EXPORTS

\begin{tabular}{lrrrrrrrrr}
\hline \hline & 1938 & 1948 & 1958 & 1960 & 1962 & 1964 & 1966 & 1968 & 1970 \\
\hline United States & 2.34 & 2.12 & 1.19 & 1.24 & 2.07 & 2.00 & 3.11 & 3.77 & 1.50 \\
United & & & & & & & & & \\
$\quad$ Kingdom & 6.09 & 6.83 & 5.09 & 6.31 & 7.50 & 10.45 & 9.25 & 12.62 & 11.27 \\
Western & & & & & & & & & \\
$\quad$ Europe a & 83.05 & 80.85 & 80.80 & 78.10 & 82.13 & 77.72 & 76.28 & 75.32 & 79.68 \\
EEC & 80.83 & 78.23 & 77.19 & 72.51 & 78.23 & 72.16 & 69.2 & 66.65 & 70.92 \\
France & 72.15 & 74.86 & 68.86 & 59.78 & 59.58 & 41.65 & 35.10 & 22.69 & 26.66 \\
Germany & 2.39 & .56 & 2.96 & 5.22 & 7.90 & 16.25 & 19.52 & 16.84 & 20.44 \\
Italy & 3.50 & 1.05 & 3.24 & 4.63 & 6.07 & 5.76 & 7.66 & 15.17 & 14.72 \\
Sino Soviet & .66 & .32 & .84 & 2.42 & 2.8 & 3.34 & 2.77 & 4.21 & $1.87 \mathrm{~b}$ \\
Japan & .08 & .02 & .16 & .43 & .28 & .18 & .26 & .28 & .66 \\
\hline
\end{tabular}

a Austria, Belgium, Denmark, Finland, France, Federal Republic of Germany, Greece, Iceland, Ireland, Italy, Malta, Luxembourg, Netherlands, Norway, Portugal, Spain, Sweden, Switzerland, Turkey, Yugoslavia.

b Incomplete data.

The picture for Latin America is a little more complicated (tables 3 and 4). Over the entire period, there appears initially to have been no such bilateral disengagement between center and periphery. Trade with the dominant nation, the United States, seemed to remain relatively constant, or even increase, between 1938 and 1970. The United States' share of Latin American exports remained around 31 percent, while imports advanced from 33.8 percent to 41.1 percent.

Yet this overall impression masks an important trend reversal. In both imports and exports, the United States' proportion rose sharply following 1938, with World War II and its aftermath, and then gradually but almost steadily declined. Latin American imports of US goods fell off from a peak of 58.1 percent beginning in 1948, and exports fell from 44.9 percent in 1958.

As in the case of North Africa, disengagement of the region from its dominant external partner was largely compensated for by intensified interaction with other central states. The earlier American rise came largely at the expense of Western Europe. The subsequent decline brought re-normalization in the sense that Western European states regained lost territory. Latin American exports to Western Europe advanced from 21.9 percent in 1948 to 30.4 percent in 1970, bettering their prewar mark of 29.4 percent. The Western European share of Latin American imports had been 34.7 percent in 1938. Postwar trade did not regain this level but did rise from 13.8 percent in 1948 to 26.3 percent in 1970 - after recovering from a dip in the early 1960s related to "Buy American" incentives suggested by the Alliance for Progress.

There was a considerable relative increase in intra-Latin American trade, which approximately doubled between 1938 and 1970. 
Nevertheless, the total rise over 32 years was less than 6 percent; and by the end of the period it still accounted for less than 15 percent of total Latin American trade. Moreover, even these figures may exaggerate the results. Dummy corporations, subsidiaries, holding companies, final assembly plants, and many other devices existed through which central businessmen took advantage of free trade areas, common markets, and other preferential regional tariff agreements in the Third World. In such ways, central products could be sold under local labels and continue to penetrate Latin American commerce in less obvious ways.

TABLE 3. SOURCE OF LATIN AMERICAN IMPORTS AS A PERCENTAGE OF TOTAL IMPORTS

\begin{tabular}{lrrrrrrrrr}
\hline \hline & 1938 & 1948 & 1958 & 1960 & 1962 & 1964 & 1966 & 1968 & 1970 \\
\hline United States & 33.84 & 58.12 & 49.39 & 45.24 & 43.11 & 45.10 & 43.67 & 42.43 & 41.08 \\
United & & & & & & & & & \\
$\quad$ Kingdom & 13.08 & 8.27 & 5.34 & 5.87 & 5.62 & 5.08 & 4.44 & 4.91 & 4.57 \\
Western & & & & & & & & & \\
$\quad$ Europe a & 34.73 & 13.83 & 24.30 & 26.79 & 28.58 & 24.51 & 25.39 & 26.06 & 26.32 \\
EEC & 28.88 & 8.44 & 16.21 & 20.23 & 21.95 & 18.49 & 18.93 & 18.84 & 18.98 \\
Latin America & 7.76 & 11.54 & 10.52 & 9.77 & 9.74 & 12.68 & 13.68 & 13.63 & 13.21 \\
Sino Soviet & 2.07 & .59 & .78 & 2.25 & 1.42 & 1.43 & 1.49 & 1.32 & .95 \\
Japan & $\ldots$ & $\ldots$ & $\ldots$ & 2.75 & 3.90 & 3.47 & 4.21 & 4.56 & 6.22 \\
\hline
\end{tabular}

"Austria, Belgium, Denmark, Finland, France, Federal Republic of Germany, Greece, Iceland, Ireland, Italy, Malta, Luxembourg, Netherlands, Norway, Portugal, Spain, Sweden, Switzerland, Turkey, Yugoslavia.

TABLE 4. DESTINATION OF LATIN AMERICAN EXPORTS AS A PERCENTAGE OF TOTAL EXPORTS

\begin{tabular}{lcrrrrrrrr}
\hline \hline & 1938 & 1948 & 1958 & 1960 & 1962 & 1964 & 1966 & 1968 & 1970 \\
\hline United States & 31.0 & 38.26 & 44.93 & 41.33 & 37.43 & 34.35 & 34.16 & 33.99 & 30.45 \\
United & & & & & & & & & \\
$\quad$ Kingdom & 17.74 & 12.91 & 8.52 & 9.10 & 8.02 & 6.79 & 6.40 & 6.11 & 4.64 \\
Western & & & & & & & & & \\
$\quad$ Europe a & 29.37 & 21.88 & 21.23 & 22.96 & 25.81 & 27.73 & 27.57 & 26.33 & 30.39 \\
EEC & 24.85 & 14.22 & 14.33 & 18.44 & 20.46 & 21.61 & 20.56 & 19.50 & 22.24 \\
Latin America & 5.98 & 9.03 & 9.13 & 8.03 & 7.46 & 9.54 & 10.56 & 11.85 & 11.65 \\
Sino Soviet & 1.44 & 1.41 & 1.38 & 1.87 & 2.17 & 2.98 & 3.60 & 1.41 & 1.61 \\
Japan & $\ldots$ & $\ldots$ & $\ldots$ & 2.43 & 3.23 & 4.34 & 4.41 & 5.32 & 6.73 \\
\hline
\end{tabular}

a Austria, Belgium, Denmark, Finland, France, Federal Republic of Germany, Greece, Iceland, Ireland, Italy, Malta, Luxembourg, Netherlands, Norway, Portugal, Spain, Sweden, Switzerland, Turkey, Yugoslavia. 
In order to describe overall trade relations between each region and the center, we can combine the various crosscurrents into aggregated statistics-EIp, EIc. When we do so, it appears that both individual cases of drift and more general pluralization must be considered within the framework of the continuing dominance of the aggregate center. In a pattern of relatively stable asymmetry, the center remains extremely important to the periphery while the periphery is relatively insignificant for the center. Table $\mathbf{5}$ shows that EIp increased slightly for North Africa, from 171.99 in 1938 to 180.09 in 1970, while EIc remained relatively stable from 1960 through 1970. For Latin America, EIp varied between 162 and 156 from 1938 to 1970, while EIc gradually declined from 15.4 in 1960 to 10.43 in $1970 .^{5}$

TABLE 5. MUTUAL ECONOMIC IMPORTANCE OF PERIPHERY AND CENTER: NORTH AFRICA, LATIN AMERICA

\begin{tabular}{lcccc}
\hline \hline & \multicolumn{2}{c}{ North } & Africa & \multicolumn{2}{c}{ Latin America } \\
& Elp & Elc & Elp & Elc \\
\hline 1938 & 171.99 & $\ldots$ & 161.81 & $\ldots$ \\
1948 & 173.95 & $\ldots$ & 156.66 & $\ldots$ \\
1958 & 176.07 & 2.51 & 157.12 & $\ldots$ \\
1960 & 176.38 & 2.91 & 160.79 & 15.40 \\
1962 & 180.45 & 2.87 & 162.07 & 14.73 \\
1964 & 176.18 & 2.72 & 158.12 & 12.97 \\
1966 & 178.18 & 3.00 & 156.00 & 12.10 \\
1968 & 176.08 & 2.75 & 156.48 & 11.28 \\
1970 & 180.09 & 157.66 & 10.43 \\
\hline
\end{tabular}

Sources: Direction of Trade: A Supplement to International Financial Statistics, Annual 1960-1964, 2 (Washington: International Monetary Fund and International Bank for Reconstruction and Development, 1965).

Direction of Trade, Annual 1966-1970, 7 (Washington: International Monetary Fund and International Bank for Reconstruction and Development, 1971).

Direction of International Trade, Annual Issue, Statistical Papers, Series T, 10, 8 (New York: United States and International Monetary Fund, 1971).

The asymmetry of relations-in which the central nations remain more important to the peripheral ones than the peripheral states to the center-suggests important structural limits to the bargaining position of most developing countries. Other things being equal, decision makers in Third World regions, supplying and consuming only small portions of central products, wield limited incentives or constraints. At the same time, their massive structural dependence on the central nations makes them acutely vulnerable to central pressures. However, other things are rarely equal. Pluralization may offer opportunities to Third World negotiators, particularly where

${ }^{5}$ If we were to add the Soviet Union, China, Poland, and Czechoslovakia to the center, as does Domínguez, the asymmetry would become even more pronounced. 
product strength also exists. In many cases Third World nations are able to negotiate from strong positions-for example, where the periphery exports commodities (like oil and gas) that are crucial for the continued functioning of highly industrialized societies. Moreover, the general attempt by Third World nations to diversify production, both for export and for domestic consumption, should help ease some of the problems of economies previously dominated by a limited number of primary products.

Pluralization provides room for some choice of partners, thereby increasing the range of possible coalitions available to Third World statesmen. Pluralization also implies somewhat greater independence in the preparation of both foreign and domestic policy-for example, in considering the balance of benefits and costs of national expropriation and ownership of foreign investments. Thus, if the Algerians cannot reach agreement with the French on oil and gas, they nationalize production and sell to the United States.

Yet one should not make too much of pluralization. Its benefits to the Third World depend to some extent on the dynamics of free competition in the center. Instead of this, there may be substantial cooperation among the central nations. Common policies and positions emerge from international organizations such as the World Bank group and the OECD. Multinational corporations, with headquarters in central nations, may control important sectors of trade, regardless of its formal national origins.

The dynamics of drift and pluralization in international trade indicate that relations between the center and the peripheries of the international system are much more complex than they were just a few generations ago. Nevertheless, the asymmetrical pattern of transactions today is similar in the aggregate to that which existed before World War II. If there is to be a more fundamental transformation in relations between international regions, we must look for it not in the past but in the future. 